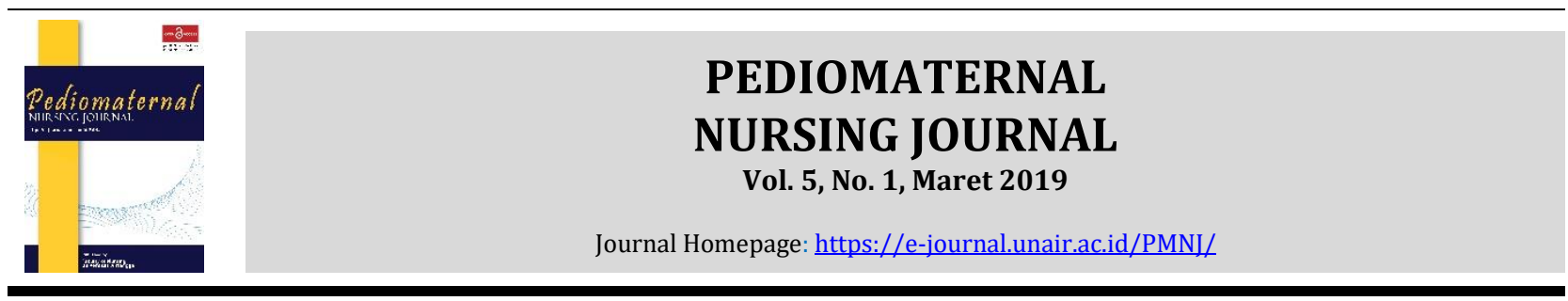

Original Research

\title{
Dukungan Suami Bukan Faktor Utama Kualitas Hidup Akseptor KB IUD
}

\author{
(Husband Support is not the Main Factor of Quality of Life for IUD Contraceptive Acceptor)
}

\author{
Bella Putri Sinta Prastika, Ni Ketut Alit Armini, dan Retnayu Pradanie
}

Fakultas Keperawatan, Universitas Airlangga, Surabaya, Jawa Timur, Indonesia

\author{
ARTICLE HISTORY \\ Received: March 17, 2019 \\ Accepted: April 13, 2019

\section{KEYWORDS} \\ husband's support; quality of \\ life; contraception; IUD; women \\ of childbearing age
}

\section{CORRESPONDING AUTHOR}

Bella Putri Sinta Prastika bellaputrisinta10@gmail.com Fakultas Keperawatan, Universitas Airlangga, Surabaya, Jawa Timur, Indonesia

\begin{abstract}
Introduction: The use of low IUD can affect the quality of family life. One of the reasons for using $\mathrm{KB}$ is because of the expensive number of children, which is a mayor influence for couples of childbearing ages in improving their welfare. The lower the use of contraception, the lower the quality of life of IUD KB acceptor. The purpose of this study was to explain the relationship between husband's support and the quality of life of family planning acceptors.

Methods: The design of this study is correlational with a cross-sectional approach. The population in this study were acceptors of IUD KB in the Mulyorejo Health Center Surabaya Working Area. The sample of 92 women of childbearing age acceptors of IUD $\mathrm{KB}$ was obtained by purposive sampling. Independent partners support variable. The dependent variable is the quality of life status. Data collection using partners support questionnaire and quality of life according to WHOQOL-BREF. Test statistics with Spearman's rho test.

Results: There was no significant relationship between lifestyle and quality of life ( $\mathrm{p}=$ $0.421, r=0.085$ ).

Conclusion: The husband's most supportive was that they supported the use of family planning. The factor of husband's support related to quality of life is emotional support, intellectual support, appreciation support, and information support. The majority of respondents can play an independent role in improving their quality of life, starting from making the best decisions for their health in the use of IUD KB. Husband's support is not always the biggest contributor to improving quality of life, but there are other factors that need to be considered. Further research is needed on other factors related to the quality of life of family planning acceptors.
\end{abstract}

Cite this as:

Prastika, B. P. S, Armini, N. K. A., \& Pradanie, R. (2019). Dukungan Suami Bukan Faktor Utama Kualitas Hidup Akseptor KB IUD. Pediomaternal Nurs. J., 5(1), 25-30.

\section{PENDAHULUAN}

Indonesia merupakan Negara berkembang dengan masalah kependudukan yang muncul adalah jumlah penduduk besar dengan laju pertumbuhan penduduk yang relative tinggi, penyebaran penduduk yang tidak merata, struktur penduduk muda, kualitas penduduk yang masih harus ditingkatkan (1). Kualitas hidup yang rendah dikarenakan penggunaan kontrasepsi yang rendah (2). Kualitas hidup yang rendah dikarenakan penggunaan kontrasepsi yang rendah (2). Dari hasil penelitian (3), didapatkan 31 wanita usia subur, 25 diantaranya melaporkan kehamilan yang tidak terkontrol dan merasa kurang nyaman dalam jumlah anak yang banyak. Hal ini menimbulkan kesejahteraan akseptor KB perlu di perhatikan. Menurut penelitain (4), efek kontrasepsi yang sangat baik dengan keamanan dan akseptabilitas, terutama dalam hubungan dengan pemeliharaan kualitas hidup yang baik, seksualitas dan penurunan desminore. Kualitas hidup baik didapatkan dari gaya hidup yang sehat. Dukungan suami yang diberikan dapat berupa dukungan informasional, dukungan instrumental, dukungan emosional, dan dukungan penilaian. Faktor 
pendorong adalah dukungan suami, keluarga. tokoh masyarakat, sikap petugas, dan teman (2).

Prevalensi pasangan usia subur (PUS) yang menjadi peserta KB berdasarkan data survei demografi dan kesehatan Indonesia (SDKI) pada tahun 2012, menunjukan tingkat kesertaan KB di antara pasangan usia subur mencapai $61,9 \%$. IUD merupakan kontrasepsi yang digunakan oleh $18 \%$ wanita usia reproduktif di Asia dan lebih dari 40\% di China (5). Berdasarkan informasi data pokok kota Surabaya tahun 2015 jumlah pengikut KB dari tahun 2014 ke tahun 2015 mengalami penurunan. Dari total 86.200 akseptor, di tahun 2014 hanya terdata sekitar 73.890 akseptor baru. Data di Puskesmas Mulyorejo Surabaya didapatkan data bahwa, jumlah pasangan usia subur di Puskesmas Mulyorejo sebanyak 4.220 orang dan jumlah peserta KB aktif pada bulan April 2016 sebanyak 3.008 atau sebesar $71.2 \%$, dengan prosentase pemakaian alat kontrasepsi IUD sebanyak 120 orang $(4,16 \%)$. Berdasarkan hasil studi pendahuluan peneliti di Puskesmas Mulyorejo pada tanggal 20 Oktober 2018 berupa wawancara dengan 10 wanita usia subur, 7 diantaranya menyatakan didukung oleh suami dalam pemilihan $\mathrm{KB}$ dan merasakan kualitas hidupnya lebih baik, karena anaknya sedikit dan hidupnya lebih tertata. Dua diantaranya merasa ragu dalam menggunakan $\mathrm{KB}$ karena takut gemuk dan tidak bisa memuaskan suami. Satu diantaranya mengatakan bahwa hidupnya sudah cukup baik sehingga tidak menggunakan KB.

Menurut (6), ibu yang tidak menggunakan MKJP khususnya IUD dan Implant mempunyai alasan karena efek samping $17,1 \%$, suami tidak setuju 0,8\%, dan tidak nyaman 5,1\%.Faktor dukungan suami sangat mempengaruhi ibu dalam pemilihan alat kontrasepsi yang cocok (7). Semakin baik dukungan suami yang diberikan maka akan meningkatkan kemampuan istri dalam menjaga kesehatan untuk meningkatkan kualitas hidupnya (8). Dampak psikologis pada keluarga (WUS) seringkali muncul seperti kurang percaya diri dengan keadaan tubuh. Dampak jangka panjang pada keluarga yang dapat ditimbulkan apabila tidak mengikuti program keluarga berencana dapat terjadi peningkatan jumlah penduduk, kekurangan pangan dan gizi sehingga kesehatan masyarakat yang buruk, pendidikan rendah, kurangnya lapangan pekerjaan, tingkat kelahiran dan kematian yang tinggi khususnya di negara berkembang (9).

Dalam pemilihan metode kontrasepsi semua wanita usia subur memiliki beberapa faktor pertimbangan, antara lain dari faktor pasangan, faktor kesehatan dan faktor dari metode kontrasepsi itu sendiri, dimana didalam ketiga faktor tersebut terdapat faktor pekerjaan, persepsi efektifitas, persepsi efek samping dan dukungan suami (10). Pertimbangan penggunaan kontrasepsi juga didasarkan atas dukungan dari suami (11). Peran pria dalam program KB adalah sebagai peserta KB, mendukung (memutuskan bersama), dalam penggunan kontrasepsi, merencanakan jumlah anak dalam kehidupan bersama (Abu Bakar, 2014). Solusi lainnya adalah dengan penggunaan kontrasepsi yang terus-menerus, karena kontrasepsi mampu meningkatkan perilaku seksual dan kualitas hidup perempuan (12). Dari latar belakang diatas sehingga membuat peneliti ingin mengetahui lebih jelas tentang hubungan dukungan suami dengan kualitas hidup akseptor KB IUD.

\section{METODE}

\subsection{Desain}

Penelitian ini adalah penelitian korelasional dengan pendekatan cross sectional. Populasi dalam penelitian ini adalah seluruh akseptor KB IUD di wilayah Puskesmas Mulyorejo Surabaya dari bulan November sampai Desember 2018.

\subsection{Populasi, sampel, dan sampling}

Populasi dalam penelitian ini adalah seluruh akseptor KB IUD di wilayah Puskesmas Mulyorejo Surabaya dari bulan November sampai Desember 2018. Sampel dalam penelitian ini yaitu WUS (18-40 tahun). Sampel ditentukan dengan teknik purposive sampling, yaitu sebanyak 92 responden. Instrumen yang digunakan dalam penelitian berisikan 16 pertanyaan dukungan suami dan 26 pertanyaan kualitas hidup dengan disediakan pilihan jawaban di dalamnya.

\subsection{Variabel}

Variabel independen dalam penelitian ini adalah dukungan suami dan variabel dependen dalam penelitian ini adalah kualitas hidup.

\subsection{Instrumen}

Dukungan suami menggunakan intrumen yang dimodifikasi dari peneliti (13). Kuesioner ini menggunakan skala likert dengan pilihan jawaban sangat sering, sering, jarang, dan tidak pernah dan terdapat 16 pertanyaan. Setelah di ketahui skor total kemudian dikategorikan menjadi dukungan suami yang mendukung dengan nilai : 9-16 dan tidak mendukung dengan nilai: 0-8. Dari hasil validitas menunjukkan nilai $r$ hitung $>r$ tabel maka seluruh butir soal pada kuesioner bernilai valid dan hasil uji realibilitas di dapatkan koefisien Cornbach's alpha sebesar 0,868 maka kuesioner termasuk sangat reliable.

Kualitas hidup menggunakan instrumen WHOQOL-BREF dari peneliti WHOQOL Group 1997. Kuesioner ini terdiri dari 26 pertanyaan dan jawaban menggunakan skala likert. Setelah di ketahui skor total kemudian dikategorikan menjadi kualitas hidup rendah dengan nilai: < 43, kualitas hidup sedang dengan nilai: 44-86, dan kualitas hidup tinggi dengan nilai: > 87. Dari hasil validitas menunjukkan nilai $r$ hitung > $r$ tabel maka seluruh butir soal pada kuesioner bernilai valid dan hasil uji realibilitas di dapatkan koefisien Cornbach's alpha sebesar 0,772 maka kuesioner termasuk sangat reliable. 


\subsection{Prosedur}

Peneliti memberikan penjelasan penelitian dan informed concent untuk ditandatangani oleh responden. Memberikan kuesioner tentang dukungan suami dan kualitas hidup untuk diisi oleh responden, namun karena kesibukan responden kuesioner tidak langsung diisi dan ditunggu oleh peneliti. Pengisian kuesioner dilakukan secara kunjungan rumah. Setelah semua responden mengisi kuesioner dikumpulkan menjadi satu kemudian responden mendapatkan reward dari peneliti.
Setalah itu peneliti mengambil dan mengecek ulang apakah kuesioner sudah terisi semua atau belum.

\subsection{Analisis}

Penelitian ini dilakukan analisis dengan IBM SPSS Statistic 25 dengan uji sperman rho dengan tingkat signifikan $\alpha \leq 0.05$.

\subsection{Ethical Clearance}

Protokol penelitian ini sudah lolos uji etik di di Fakultas Keperawatan dengan No sertifikat: 1241KEPK. Analisis yang dilakukan pada penelitian ini

Tabel 1. Karakteristik akseptor KB IUD di Puskesmas Mulyorejo

\begin{tabular}{|c|c|c|c|c|}
\hline No. & & Demografi Responden & $\mathbf{N}$ & $\%$ \\
\hline \multirow{2}{*}{1} & \multirow{2}{*}{ Usia Ibu } & 18-40 tahun & 82 & 89,1 \\
\hline & & $>40$ tahun & 10 & 10,9 \\
\hline \multirow{2}{*}{2} & \multirow{2}{*}{ Suku/Etnis } & Jawa & 81 & 88 \\
\hline & & Madura & 11 & 12 \\
\hline \multirow{2}{*}{3} & \multirow{2}{*}{ Agama } & Islam & 84 & 91,3 \\
\hline & & Non-Islam & 8 & 8,7 \\
\hline \multirow{3}{*}{4} & \multirow{3}{*}{ Pekerjaan } & Ibu rumah tangga & 61 & 66,3 \\
\hline & & Pedagang & 12 & 13 \\
\hline & & Pegawai Swasta & 19 & 20,7 \\
\hline \multirow{4}{*}{5} & \multirow{4}{*}{ Pendidikan Terakhir } & SD & 20 & 21,7 \\
\hline & & SMP & 35 & 38 \\
\hline & & SMA & 26 & 28,3 \\
\hline & & PT & 11 & 12 \\
\hline \multirow{3}{*}{6} & \multirow{2}{*}{ Pendapat per bulan } & $<$ UMR & 82 & 89,1 \\
\hline & & > UMR & 10 & 10,9 \\
\hline & \multirow{3}{*}{ Jumlah anak } & $1-2$ & 77 & 83,7 \\
\hline \multirow[t]{2}{*}{7} & & $3-4$ & 7 & 7.6 \\
\hline & & $>4$ & 8 & 8,7 \\
\hline \multirow{3}{*}{8} & \multirow{3}{*}{ Lama pemakaian } & $<1$ tahun & 15 & 16,3 \\
\hline & & $1-3$ tahun & 34 & 37 \\
\hline & & $>4$ tahun & 28 & 30,4 \\
\hline \multirow{4}{*}{9} & \multirow{4}{*}{ Keluhan selama pemakaian } & Timbul jerawat & 21 & 22,8 \\
\hline & & Flek dan tidak teratur mens & 20 & 21,7 \\
\hline & & Mulas/ nyeri & 24 & 26,1 \\
\hline & & Tidak ada & 27 & 29,3 \\
\hline
\end{tabular}

Tabel 2. Distribusi responden berdasarkan dukungan suami di Puskesmas Mulyorejo Surabaya

\begin{tabular}{llccc}
\hline \multirow{2}{*}{ Parameter } & \multicolumn{1}{c}{ Pernyataan } & $\begin{array}{c}\text { Ya } \\
\text { (1) }\end{array}$ & $\begin{array}{c}\text { Tidak } \\
\text { (0) }\end{array}$ & \multicolumn{1}{c}{ X } \\
& & 85 & 7 & 0,92 \\
Dukungan Emosional & Suami peduli perubahan fisik saya & 92 & 0 & 1,00 \\
& Suami mendukung menggunakan KB IUD & 75 & 17 & 0.82 \\
& Suami mendengarkan keluhan saat haid & 76 & 16 & 0,83 \\
& Suami memberi dukungan saat cemas & 87 & 5 & 0,95 \\
& Suami membiayai penggunaan KB & 72 & 20 & 0,78 \\
Dukungan Instrumental & Suami mengantar kontrol & 65 & 27 & 0,71 \\
& Biaya layanan kesehatan lain dibantu suami & 59 & 33 & 0,64 \\
& Saat waktu luang suami selalu menemani & 61 & 31 & 0,66 \\
& Suami membiarkan dan mendukung pemilihan KB & 53 & 39 & 0,58 \\
& Suami ikut pengambilan keputuhan dalam KB & 56 & 36 & 0,61 \\
& Suami memuji saya selama menggukan KB & 56 & 36 & 0,61 \\
& Suami menyediakan segala kebutuhan untuk kesehatan & 53 & 39 & 0,58 \\
& Bila waktu luang kami selalu berdiskusi & 51 & 41 & 0,55 \\
& Suami mencari informasi Kontrasepsi di media social, & 51 & 36 \\
& artikel, dan majalah & 54 & 38 & 0,59 \\
& Suami mengijinkan untuk ikut penyuluhan KB & 63 & 29 & 0,67 \\
\hline
\end{tabular}


adalah uji analisis Spearman rho di SPSS. Dengan analisis inferensialnya (uji signifikan) bertujuan untuk menganalisis hubungan dukungan suami dengan kualitas hidup akseptor KB IUD. Skala data yang digunakan untuk kuesioner adalah ordinal.

\section{Hasil}

Sampel penelitian sebagian besar usia 18-40 tahun $(89,1 \%)$, mayoritas suku jawa (88\%), bekerja sebagai IRT $(66,3 \%)$, pendidikan terakhir SMP (38\%), pendapatan perbulannya $<\operatorname{UMR}(89,1 \%)$, responden paling banyak jumlah anak 1-2 (83,7\%), dengan lama pemakaian KB IUD 1-3 tahun (37\%), dan mayoritas selama pemakaian tidak mengalami keluhan $(29,3 \%)$. [Tabel 1].

Distribusi tersebut menjelaskan menunjukkan bahwa data dukungan suami dengan jumlah 15 pertanyaan dihubungkan dengan parameter pada definisi operasional. Parameter 1 terkait dukungan yang berupa kehadiran dalam hal - hal yang dapat memberikan keuntungan emosional dan berpengaruh pada tingkah laku penerimanya (12). Dukungan patner atau suami yang baik dapat menentukan kualitas hidup seseorang istri. Karena suami sebagai pendamping istri dalam segala hal terutama dalam hal pengambilan keputusan. Sejalan dengan penelitian (12), mengatakan bahwa ada hubungan keluarga berencana, pengetahuan, sikap / dukungan keluarga, dan penggunaan kontrasepsi dalam kualitas hidup dalam kesehatan.

Jenis dukungan suami yang mendapatkan skor paling tinggi yaitu dukungan emosional sedangkan yang mendapat skor paling rendah yaitu dukungan informasi. Dukungan informasi yang diberikan mampu membantu individu dengan memberikan informasi yang berguna dan berhubungan dengan masalah yang telah dihadapinya (12) Dukungan suami berupa materi, emosi, penghargaan dan

Tabel 3. Analisis hubungan dukunga suami dengan kualitas hidup akseptor KB IUD di Puskesmas Mulyorejo

\begin{tabular}{|c|c|c|c|c|c|c|}
\hline \multirow{3}{*}{ Dukungan Suami } & \multicolumn{4}{|c|}{ Kualitas Hidup } & \multirow{2}{*}{\multicolumn{2}{|c|}{ Total }} \\
\hline & \multirow{2}{*}{$\begin{array}{c}\text { Sedang } \\
\mathrm{F}\end{array}$} & \multicolumn{3}{|c|}{ Tinggi } & & \\
\hline & & $\%$ & $\mathbf{F}$ & $\%$ & $\Sigma$ & $\%$ \\
\hline Mendukung & 66 & 83,5 & 13 & 16,5 & 79 & 85,9 \\
\hline \multirow[t]{3}{*}{ Tidak mendukung } & 12 & 92,3 & 1 & 7,7 & 13 & 14,1 \\
\hline & & & & & 92 & 100 \\
\hline & \multicolumn{4}{|c|}{ Spearman rho $p=0,421 \mathrm{r}=0,085$} & & \\
\hline
\end{tabular}

emosional penyumbang skor terbanyak karena mayoritas responden mendapat dukungan emosional dari suami. Item pertanyaan tentang "suami mendukung penggunaan KB IUD" menjadi item pertanyaan dengan skor tertinggi yaitu 92 responden menjawab iya, yang artinya mendapat dukungan dari suami dalam pemilihan KB [Tabel 2].

Mayoritas responden yang mendapat dukungan dan kualitas hidup sedang sebanyak 66 orang $(83,5 \%)$. Dan responden dengan dukungan suami dengan kualitas hidup tinggi sebesar 13 orang $(16,5 \%)$. Hasil uji statistik pada $r$ tabel didapatkan 0,085 dengan $p=0,421$ yang berarti variabel dukungan suami dan kualitas hidup akseptor KB IUD tidak ada korelasi yang signifikan [Tabel 3].

\section{PEMBAHASAN}

4.1 Hubungan antara dukungan suami dengan kualitas hidup akseptor KB IUD

Mayoritas akseptor KB IUD mendapat dukungan yang tinggi sehingga kualitas hidupnya sedang, sebanyak 66 responden (83,55\%). Dukungan sendiri merupakan informasi dari orang lain bahwa ia dicintai dan diperhatikan, memiliki harga diri dan dihargai, serta merupakan bagian dari jaringan komunikasi dan kewajiban bersama. Dukungan dapat juga diartikan sebagai informasi verbal dan non verbal, saran dan bantuan yang nyata atau tingkah laku yang diberikan oleh orang - orang yang akrab dengan subjek di dalam lingkungan sosialnya atau informasi harus saling berkesinambungan, sehingga dapat memberikan pengaruh pada penggunaan kontrasepsi dan upaya menjaga kualitas hidup yang maksimal. Informasi pelayanan KB dapat di dapatkan dari media seperti Koran, elektronik, atau datang ke Puskesmas dan melakukan konseling rutin. Sesuai dengan penelitian (12) yang menyatakan bahwa ada hubungan penyediaan layanan kesehatan untuk meningkatkan kualitas hidup seseorang. Hal ini perlu dilakukan agar istri dan suami dapat saling memahami untuk penggunaan KB yang cocok dan sesuai kebutuhan mereka.

Responden yang tidak mendapatkan dukungan suami dan kualitas hidup rendah sebanyak 12 responden (92,3\%). Ini terjadi karena dianggap tanpa dukungan suami dan tidak rutin harus diantar kontrol maupun ke pelayanan kesehatan istri dianggap telah mampu mandiri serta melakukannya sendiri. Mengambil keputusan dengan baik demi kesehatannya sendiri. Belum paham secara baik apa itu kontrasepsi, guna, dan keuntungannya. Sehingga suami jarang untuk mencari informasi tentang kontrasepsi maupun konsultasi ke pelayanan KB. Sebaliknya responden yang tidak mendapat dukungan suami tapi kualitas hidupnya tinggi sebesar 1 orang (7.7\%). Kebanyakan orang dengan kemampuan mandiri dalam menghadapi hidup sangat penting. Responden yang telah mampu melakukan sendiri tanpa dukungan suami ialah dai yang sudah bekerja sendiri dan mengatur pengeliaran dirumah sendiri seperti karyawan, atau wiraswasta mandiri. Sehingga tidak membutuhkan banyak 
bantuan dari suami. Dan suami hanya sebatas tahu apa yang akan diambil untuk kesehatannya.

Dari hasil uji statistik didapatkan bahwa dukungan suami tidak berhubungan signifikan dengan kualitas hidup akseptor KB IUD di wilayah kerja puskesmas Mulyorejo Surabaya. Didapatkan suami yang mendukung dengan kualitas hidup tinggi sebesar 13 responden (16,5\%). Dapat diambil kesimpulan bahwa dengan dukungan suami yang baik, samgat diperlukan dalam kehidupan seharihari. Semakin tinggi dukungan suami maka semakin baik pula kualitas hidup seseorang dan semakin sejahtera keluarga itu. Menurut (12) dukungan suami merupakan ungkapan yang dapat diwujudkan dengan penghargaan, kasih sayang, toleran dan membantu patner atau pasangannya dalam menghadapi suatu masalah. Dalam teori Lawrence W, Green salah satu faktor pendorong terbentuknya perilaku adalah keluarga (12). Hal ini dikarenakan keluarga yang paling dengat dengan keluarga dan selalu memberi semangat dalam bentuk dan kondisi apapun. Suami merupakan anggota keluarga paling dekat dan mampu dipercaya untuk memberikan dukungan kepada istri (12). Diharapkan keluarga sejahtera dilandasi dengan perilaku yang baik. Perilaku suami dan dukungan yang baik sangat diperlukan guna mempertahankan dan meningkatkan kualitas hidup.

Penelitian ini memberikan gambaran bahwa suami harus lebih perhatikan istri dan mendukung dari semua aspek. Hal ini dapat diwujudkan dalam bentuk mengantar istri konsultasi ke bidan, mengingatkan dalam kontrol jika ada masalah dalam penggunaan kontrasepsi dan mendampingi sang istri saat pemasangan kontrasepsi. Penelitian ini sejalan dengan (12), yang menghasilkan bahwa ada hubungan antara pendidikan dan dukungan suami dalam penggunaan AKDR. Semakin tinggi pendidikan dan ilmu seseorang maka orang tersebut akan lebih menyadari apa yang dibutuhkan dalam kehidupannya. Penelitian lain dari (12), mengatakan ada hubungan antara dukungan suami terhadap kepatuhan akseptor KB dalam melakaukan keluarga berencana. Sedikitnya dukungan suami kemungkinan dikarenakan istri sudah dapat mandiri dengan segala keputusan yang terbaik dalam pemilihan kontrasepsi. Suami hanya mendukung keputusan istri dan membiayai saja. Didukung dengan Kualitas hidup sendiri merupakan penilaian seseorang sejauh mana dapat merasakan dan menikmati terjadinya segala peristiwa penting dalam kehidupannya sehingga kehidupannya menjadi sejahtera.

Faktor dukungan suami sebagai pasangan dari akseptor KB berkontribusi cukup besar sebagai pendukung sekaligus pengatur istri dalam penggunaan kontrasepsi. Suami yang memiliki dukungan baik belum tentu mempengaruhi istri dalam mencapai kualitas hidup yang baik pula. Penelitian ini tidak sesuai dengan penelitian (12), menyatakan bahwa peningkatan kualitas hidup berdasarkan lam penggunan dan dukungan suami. Mayoritas lama penggunaan KB IUD yaitu 1-3 tahun dan responden menyatakan tidak ada keluhan yang mengganggu setalah penggunan KB IUD. Dengan keluhan yang tidak ada dan kenyamanan dalam penggunaan KB IUD di harapkan ada peningkatan kualitas hidup seseorang. Dengan kualitas hidup baik maka keluarga tergolong dalam keluarga yang sejahtera.

\section{KESIMPULAN}

Akseptor KB IUD mayoritas mendapat dukungan suami, tetapi banyak istri yang dianggap mandiri secara utuh dalam menghadapi masalah maupun perawatan terbaik dalam pengambilan keputusan. Dukungan suami tidak selalu memenuhi dalam kualitas hidup dari akseptor KB IUD karena istri secara garis besar dapat mandiri dalam penentu kesehatan bagi dirinya. Kualitas hidup akseptor KB IUD tidak hanya ditentukan dengan dukungan suami yang sehat tetapi juga ditentukan dengan indikator lain seperti gaya hidup.

Masyarakat terutama akseptor KB IUD diharapkan melaksanakan program KB yang diketahui keluarga maupun suani, meskipun tidak secara langsung berhubungan dengan kualitas hidup akseptor. Petugas kesehatan memberikan dukungan kepada akseptor KB dalam penggunaaan IUD. Peneliti selanjutnya dapat dikembangkan dengan membandingkan faktor lain dengan kualitas hidup akseptor kontrasepsi IUD dengan jenis kontrasepsi homonal.

\section{UCAPAN TERIMA KASIH}

Kami mengucapkan terima kasih kepada Puskesmas Mulyorejo Surabaya untuk izin dan penerimaan kami untuk mengambil data sebagai bahan penelitian dan semua responden KB IUD yang telah bersedia menjadi responden.

\section{DAFTAR PUSTAKA}

1. Septianingrum Y, Wardani EM, Kartini Y. Factors Affecting the High Rates of 3 Month Injection Contraceptive Acceptors. 2018;5(1):15-9.

2. Skrzypulec V, Drosdzol A. Evaluation of the quality of life and sexual functioning of women using a 30- $\mathrm{m}$ g ethinyloestradiol and 3-mg drospirenone combined oral contraceptive. 2008;13(March):49-57.

3. Caruso S, Malandrino C, Cicero C, Ciancio F, Cariola M, Cianci A. Continued-Regimen : Pilot Study. 2012;460-6.

4. Neri M, Piras B, Paoletti AM, Vallerino V, Ronchetti C, Taccori V, et al. Long-acting reversible contraception ( LARC) with the intrauterine system with levonorgestrel ( 6 mcg / d ): observational study on the acceptability , quality of life, and sexuality in Italian women. Gynecol Endocrinol. 2017;0(0):1-4. 
5. Keane S, Vallecoccia MS, Nseir S, MartinLoeches I. How Can We Distinguish Ventilator-Associated Tracheobronchitis from Pneumonia? Clin Chest Med [Internet]. 2018;39(4):785-96. Available from: https://doi.org/10.1016/j.ccm.2018.08.003

6. Lord JH, Rumburg TM, Jaser SS. Staying positive: Positive affect as a predictor of resilience in adolescents with type 1 diabetes. J Pediatr Psychol. 2014;40(9):968-77.

7. Maryani S, Desmarnita U, Djuwitaningsih S. Dukungan suami dalam pemilihan metode kontrasepsi jangka panjang. 2013;49-56.

8. Cristobal I, Ignacio L, De E, Perulero N, Arbat A, Canals I. One year quality of life measured with SEC-QoL in levonorgestrel $52 \mathrm{mg}$. Contraception. 2016;93(4):367-71.

9. Ferreira M, Vicente S, Duarte J, Chaves C. Quality of Life of Women with Infertility. Procedia - Soc Behav Sci. 2015;165:21-9.

10. Velonjara J, Crouthamel B, Malley GO, Wiggins M, Matemo D, John-stewart G, et al. Sexual \& Reproductive Healthcare Motherhood increases support for family planning among Kenyan adolescents. Sex Reprod Healthc. 2018;16(February):124-31.

11. Kusumaningrum R. faktor-faktor yang berhubungan dengan pasangan usia subur (pus) tidak memilih metode kontrasepsi intra uterine device (iud) di desa pucangan kecamatan kertasura kabupaten sukoharjo. 2013;

12. Caruso S, Agnello C, Romano M, Cianci S, Presti L Lo, Malandrino $\mathrm{C}$, et al. ORIGINAL RESEARCH - WOMEN' S SEXUAL HEALTH Preliminary Study on the Effect of Four-phasic Estradiol Valerate and Dienogest ( E2V / DNG ) Oral Contraceptive on the Quality of. 2011;2841-50.

13. Putri SB, Hamid AYS, Priscilla V. Karakteristik dan Strategi Koping dengan Stres Pasien Kanker Payudara dalam Menjalani Kemoterapi. J Endur [Internet]. 2017;2(3):303-11. Available from: http://ejournal.kopertis10.or.id/index.php/e ndurance/article/view/2026/785 